\title{
Some Thoughts of a Rare Book Librarian
}

$\mathrm{T}$ He United States of America has been for me a land of pleasant surprises. If I had been told in Dublin a year ago that $I$ would at the same time in 1958 be addressing members of the American Library Association in San Francisco, ${ }^{1}$ I would simply not have believed it. To be invited to the librarianship of the Huntington was the first pleasant surprise, and that was closely followed by a second: your invitation to address this meeting. I have been honored by both invitations, and I feel that this is the time to thank you most warmly for the fact that I am here as your guest. I am particularly glad, too, to have this opportunity, at the very beginning of my life in this country, of meeting so many of you whose work is with the manuscripts, rare books, and special collections in the great libraries of the United States. To know that I am one of you will go a long way towards making me feel at home in a strange, yet beautiful and friendly land, and I look forward to the privilege of membership in your association in general and to this newly-formed section of it in particular.

In the short time I have been here -some six weeks-I have been endeavoring to get acquainted with the thinking and planning which have gone towards the creation of this section within ACRL. I have read of the establishment in 1954 of a Committee on Rare Books,

1 Paper presented before the ACRL Rare Books Section on July 15 at San Francisco.

$M r$. Dougan is Librarian, Henry E. Huntington Library, San Marino, California.
Manuscripts, and Special Collections (and I quote): "to promote wider understanding of the value of rare books to scholarly research and to cultural growth; to encourage a more enlightened approach to the care, use, and recognition of rare books in all libraries, and to provide a meeting place for the discussion of problems common to the rare book librarian," and I must say it was heart-warming to see the light of day breaking through the rarified atmosphere which has so often surrounded such collections. I have read with great interest the Symposium on Rare Book Libraries and Collections in Library Trends of April, 1957, and it was good to hear Dr. Lawrence C. Wroth, your very distinguished doyen of rare book librarianship saying: "The rare book library exists to inform, enlighten, and delight its readers through collecting books, preserving them, and making them available for use." And he was ably followed by Mr. T. R. Adams, with many of whose sentiments I am wholly in agreement.

When you kindly invited me to address this meeting, the suggestion was made that I might in my talk "contrast the problems involved in operating a great British research library with those of an American research library," but fortunately this topic was not insisted on and I was generously given my own choice of subject. I was very glad of the latter alternative because in the short time I have been here I could hardly do justice to the former. I hope you will forgive me for not announcing a definite topic as the subject of this paper, and that you will accept "Some 
Thoughts of a Rare Book Librarian" as a heading for what I have gathered together for this occasion. This will involve a certain amount of personal reminiscence, I am afraid, but in so far as it is pertinent to the librarianship of rare books, manscripts, and special collections I trust I may receive your indulgence.

When I use the term "rare book" I do so for the sake of simplification, and intend by it the inclusion of manuscripts and special collections. Though unfamiliar to me, this connotation is, I understand, familiar to you; in the great libraries of the British Isles such as the British Museum, the National Libraries of Scotland and Wales, and in several of the university libraries, manuscripts are departmentalized. Under the chief librarian there is a keeper of manuscripts, who has the care of everything written by hand, whether in book form or as documents or archives; as his opposite number there is a keeper of printed books who, if he is not himself a specialist in the old and the rare, has members of his staff whose business it is to care for such. In the Huntington we have a keeper or curator of manuscripts, but the printed books are divided into two categories: rare and reference, and each department has its curator.

To those of us here, and I hope to the vast majority of the members of our profession, it is obvious that the curatorship of rare books calls for particular qualifications, some of which may be acquired through training and experience, but we must all have basically that attitude towards a book which I do not think I can describe better than an enquiring mind. I suppose that most librarians are in the profession because they have a care for books, but to have an enquiring mind about the books we handle is more than caring; it should amount to an unashamed affection for them. Since 1935, times, I hope, have changed, but it was alarming to hear a college librarian in the east of the U.S.A. lamenting the necessity for "promotional activities" in his library in the following words: "If he is not already one, he [the librarian] will be forced to become a professional booklover. Book-loving is no doubt a noble passion, praiseworthy in businessmen and other amateurs, but out of place in the temperament of the librarian." (I owe the quotation to the late Dr. Randolph G. Adams's provocative "Librarians As Enemies of Books," published in The Library Quarterly, VII (1937). Times, indeed, must have changed; a new and refreshing attitude to the book has been born and nurtured, and a gathering such as this, impossible then, has become a live reality today.

For you are rare book librarians, are you not? Because you care for more than the mere mechanics of librarianship and the compilation of statistics; you care for books themselves, books which enshrine the thoughts of master minds, books which have been in the vanguard of the march of civilization, and books which are the very warp and woof of history itself. But there is more to it even than that: you handle the first editions of these books-and what a story each could tell! You handle copies of books which have been in the libraries of great men. And you handle the very sheets of paper and vellum leaves on which men and women have first committed their thoughts to writing.

The basic duty, and indeed privilege, of a librarian is to place a book in the hands of the person who needs to read it-not literally, of course, but the mechanics of our profession should all lead to that end. We and the book fulfill our respective functions. The great bulk of the work done in our libraries is just that. The accessioning, catalog- 
ing and classification of our numerous day-to-day acquisitions for the use of our many readers is administrative and routine work which calls for the accurate use of our professional abilities. Catalogers have no time to look beyond title pages and perhaps prefaces, and the careful examination of the books themselves and of the very copies they handle is not required of them. The work of making books accessible must go on. We rare book librarians, however, have additional responsibilities and in their fulfillment we justify our appointments not only to the libraries which we serve, but also to the world of scholarship in general.

We handle a rare book, and instinctively we turn to the title page, but we have only just begun. To us it is not just another copy of, say, the first edition of Alice in Wonderland. What has this copy got to tell us? Is the binding original, or has the book been rebound? Is this copy complete? For it must be carefully collated and compared with the bibliography. Can you lay your hands on a standard bibliographical description? In other words, have you your reference books to hand? From what library did this copy come? Is there any ownership inscription anywhere? Is it, by any chance, a presentation copy from the author, and if so, can you by research establish the relationship between the donor and the recipient? These are all questions you automatically ask on these occasions, are they not? And they spring from the enquiring mind which should be fundamental in our handling of the books which come into our collections.

Sometimes the research started in an attempt to answer these questions is exciting as well as rewarding. The study of an old binding and its end-papers and any early ownership and marginal annotations often lead to the personal history of the book itself, and this in- formation can be of considerable importance to the student of history, sociology, and even of science, but also we may find notes of value to the student employed on bibliographical research. One well-known example comes to mind: the date of printing of the Gutenberg Bible is not known, but we do know that it could not have been printed after 1456. Why? Because it was noticed one day that the copy of this book in the Bibliotheque Nationale in Paris bore an inscription by its rubricator giving not only his name, but also the date when he finished his work: August, 1456.

For the first hundred years or so of their history printed books were not marketed as bound volumes; they were sold by the quire, and the cost of the book depended on the number of quires and the size of them. The purchaser saw to the binding. Here, then, in the first stage of a book's history something about its first owner may be learned from its binding; was he a collector, or was the book for use in a monastic, cathedral, or university library? And the end-papers, which are often scraps of vellum manuscripts or printer's waste in the binder's workshop, can sometimes add corroborative evidence. How often on these end-papers one finds the words: "sum liber . . ." followed by a name. It is the book itself speaking. Let us listen to the true story of a book which, from manuscript data on the title page and a study of the binding, I was able to piece together some years ago. ${ }^{2}$

This book which came into my hands to catalog and describe is a small folio volume containing the Gospels and Epistles in Low German. It was printed in Lübeck in 1506 and it is illustrated with some fifty woodcuts; a fine example of an early sixteenth-century German woodcut book, and undoubtedly of con-

2 This story was first told in The Library Review, no. 84, Glasgow, 1947. 
siderable rarity. The first thing I noticed was that the binding of plain brown calf was not contemporary but belonged to the eighteenth century. In the compartments of the back, formed by raised bands, I noticed alternating impressions in gold of the Royal Crown and Tudor Rose, and right at the foot, in small letters: "G.III." A little unusual, perhaps, but no doubt capable of a simple explanation. Let us have a look at the title page. The first thing to strike one here is the British Museum duplicate stamp and the date, 1787; this means that the book had been in the B.M. in the eighteenth century, and when it was discovered to be a duplicate it was sold. How did it get to the British Museum? The Royal Crown and "G.III" provide the clue, for the old Royal Library was presented to the B.M. in 1757, and one of the Museum's binders at a little later date no doubt put the letters "G.III" (George III) on the back to indicate at a brief glance the royal origin of the volume. But what about the Tudor Rose?

Let us look at that title page again; there is something else there as well as that ugly old B.M. stamp. (Incidentally, why have so-called librarians in the past so often disfigured beautiful old books and manuscripts with hideous stamps, laid on with the strength and lack of precision of post office clerks, to the ruination of a delightful title page or frontispiece illustration? They certainly showed that they had no affection for the precious books of which they were nominally the curators.) Yes, what is that on the title page? A scribble, and in English too. And to judge from the color of the ink and the handwriting, contemporary with the date of printing. What does it say? Listen: "Henry is my best friend." Henry . . . Tudor Rose . . . Henry . . . 1506 . . . Why, that must be Henry VIII! Let us compare other auto- graphs of his. Yes, there does not seem much doubt. Is there an extant catalog of Henry VIII's library, and would we find this book in it?

In the Public Record Office in London there is a catalog of Henry VIII's library at his Palace of Westminster in the Augmentation Office Records, vol. 160, and sure enough, on fol. 110 recto, line 10, we read Epistole et Evangelia in lingua Germanica. Moreover, all the books from this library bore a number entered on the right hand top corner of the title-other examples can be seen among the Royal Library books at the British Museum; this book has "no. 317." After the days of Henry VIII the book remained with the other books in the Royal Library and descended through successive generations of royal owners to George II. About this time it was rebound in plain calf, and decorated with the Royal Crown on the back and the Tudor Rose to show that it came from the library of the Tudor kings. Let us look at the "G.III" again; it is not very distinct ... has it been superimposed on something else? Yes, we can distinctly trace: "H.VIII." So, when it was rebound in plain calf the binder letter "H.VIII" to preserve the record that this book was originally in a binding made for Henry VIII. This gold "H.VIII" has been tampered with by a later binder at the British Museum who tried to alter it into "G.III" to make it conform with other books in the Royal Library, but he was not very successful as the original "H.VIII" can be seen quite easily beneath.

Yes, old books can tell us a lot if we listen; more than any other objects of antiquarian interest. Here we have on its own showing the story of this one from 1506 or thereabouts to 1787 . It might be possible to find out what happened to it next, but not from anything it can tell us itself. In the latter part 
of last century the book belonged to William Morris and then to C. Fairfax Murray, a great collector of early illustrated books; both their bookplates are mounted inside the front cover. Nowhere does it appear to have been recorded, however, that this was Henry VIII's copy with his autograph; it is indeed very doubtful if it would have been sold by the British Museum in 1787 had this been realized, and it looks as if this is one more example of the careless discarding of duplicates by a librarian unequipped with an enquiring mind! The book has now found its fitting home once more in the Royal Library at Windsor Castle.

In the history of book collecting there have been many such examples of discoveries made through the careful examination of copies in hand. Sometimes, however, it is the text itself and the paper it is printed on that call for our attention and, to come down to much later times, who among the older librarians here could not have been thrilled by the enquiring minds of John Carter and Graham Pollard, who in 1934 unveiled the forgeries of $\mathrm{T}$. J. Wise in their Enquiry (note the word) into the Nature of Certain Nineteenth Century Pamphlets, which is one of the best detective stories I know?

The approach of the enquiring mind, which seeks to get on intimate terms with the books we handle, leads naturally, as I said earlier, to affection and therefore care for their physical wellbeing. We learn to handle them carefully, treat them properly, and to see that others do so too. In my experience, the majority of advanced scholars who need access to our original manuscript and printed sources are sufficiently indebted to books and papers to respect their fragility and to avoid harm to them, but unhappily there are exceptions. They can often be detected at the outset by the nature of their enquiry, and such was the case at the Huntington Library a few weeks ago. We received a request from a visiting reader to see all our Books of Hours, because he was interested in the iconography of a particular, rather out-of-the-way saint. His intention was to leaf through them all in his search for this saint, involving himself as well as the library staff in considerable labor, to say nothing of possible damage to the delicate miniatures which are characteristic of these books. If he had really known what he was doing, he would have asked to see only those manuscripts which were for use in that particular area of Europe where that saint was venerated. And so, of course, for the sake of preserving our whole collection from unnecessary wear and tear, he was limited to that selection.

This anecdote has firmly directed my thoughts to the care of manuscripts, and I feel that this may be the appropriate moment to accept a suggestion that I might say a few words about the handling of the famous Irish manuscripts in Trinity College, Dublin, with which I am naturally familiar as I prepared an exhibition and catalog of them some five years ago. The most renowned, though not the oldest, is of course the Book of Kells, and as I was intimately concerned with its rebinding and subsequent display you may like to hear about that. This is the most elaborately ornamented and decorated manuscript in the world, and although its text is quite simply that of the Four Gospels in Latin, it is surprising what a lot of misconceptions and mystery surround it. Maybe its extraordinarily rich and exuberant decoration bemuses the spirit -as it has bemused mine more than once-or maybe it is that "something Irish" about it! In fact, though, it is believed that the scribes and artists pur- 
posely went out of their way to surround parts of the sacred word with these extraordinary patterns and designs in order to create mysteries which only the initiated could solve. From the highspirited American, who hailed me outside the library with the words: "Say, where's Kelly's book?" to the demure middle-aged English gentleman, who, after gazing reverently upon it for a while and failing to make anything out of the text, asked if there was a good English translation, the Book of Kells provides the Mecca for all visitors to Dublin in general and to Trinity College in particular.

In 1952 the book was displayed on a fairly steep inclined plane in its showcase and the sewing of the leaves in the old binding, which had done duty for little more than fifty years, was giving way, the process being accelerated by the gravitational pull of the heavy vellum leaves. The loosening binding was, of course, having a bad effect on the leaves themselves, which rubbed together whenever the book was opened and shut. And so, in your care of manuscripts, especially illuminated ones, may I suggest that you exhibit them preferably on a flat, or only slightly sloping surface. If you must exhibit them practically vertical they must be adequately supported, with the leaves of each part of the opened book tightly wrapped and supported as well, so that the force of gravity does not cause them to pull at the binding.

The search for a bookbinder with sufficient experience in the handling of vellum (which presents quite different problems from paper) led eventually to Mr. Roger Powell, who was at one time associated with the late Douglas Cockerell, the man who bound the Codex Sinaiticus for the British Museum. Since it was deemed inadvisable to allow the Book to leave Trinity College, a work- shop was equipped in the library itself; this also had the advantage that problems which arose in the course of the work could be dealt with promptly. When the book was pulled it was found that a considerable number of originally paired leaves had become dissociated from their partners-presumably some time ago, because the barbarous practice of oversewing had been resorted to in earlier rebindings-and the first great problem raised its head. The pairing up of the single leaves by means of linen guards, which had to be sewn on because there is no known adhesive to stick anything to vellum permanently, would lead to considerable swelling at the back of the book when the leaves were gathered into sections for sewing, and the result would be a wedge-shaped volume, very thick at the back and tapering to the fore-edge; an object not only unsatisfactory as a binding, for it could never be made rigid enough to prevent the leaves' rubbing together when handled, but it would be unsightly and ungainly into the bargain. In the end it was decided to compensate for the thick back by inserting sections of blank vellum on single guards, thereby increasing the thickness of the book at the foreedge without adding more than a fraction to the thickness of the back. If this were done between the sections or gatherings of the book, there would be the minimum interference with the text, but of course a very thick volume of more than seven inches in depth would be the result. And so the proposal was adopted that each Gospel be bound separately, but uniformly with the others, and that the whole Book of Kells in its four volumes be provided with a comprehensive case.

But before the sewing-on of the guards could begin, the bookbinder announced that it was necessary, first of all to flatten the leaves. Vellum, as you know, is 
susceptible to climatic conditions and we knew that certain leaves were creased or otherwise out of shape, but immediately we heard they were to be flattened we were naturally alarmed because we could only think of pressure from above and below and possible irreparable damage to the decorated pages. Flattening was effected by dampening each leaf (or pair of leaves, where the pair still existed) between blotting paper, and exerting gentle tension from edge to edge while it dried. The result in every case was most satisfactory; the leaves were not only flattened but freshened.

Finally the four volumes were ready for casing. Simple binding cases of oak boards with pigskin backs were made, each reinforced with additional pigskin bands at the top and bottom of the back. The finished volumes resemble very closely many of the simple fifteenthcentury "half-bindings" that have survived to this day, and so, it is hoped these too will last five hundred years. Clasps were not fitted to the boards at the fore-edges, as these when fastened exert only diminishing pressure from the edge to the back. Instead, each volume is enclosed in a carrying case fitted with a lid and spring which, when secured, exerts a uniform pressure over the whole volume when it lies closed.

I hope I have not wearied you with these descriptive details, but I do believe they contain many points of interest to all of us whose business it is to care for the physical well-being of our books and manuscripts. We were so satisfied with Mr. Powell's expert work on the Book of Kells, that he was subsequently entrusted with the rebinding of the eighthcentury Book of Durrow (estimated to be about a hundred years older than the Book of Kells, and the first fully decorated Irish manuscript of the Gospels), the Book of Dimma (also eighth-century) and the Book of Armagh, which dates from about 807. While the Book of Durrow was unbound, it was photographed for the facsimile edition to be published by the same firm which issued the Book of Kells facsimile in 1950. And since the photographer's task was eased in this way I think the results will be more satisfactory. And I should mention, since it is a point which will occur to you as rare book librarians, that once the facsimile is published Trinity College does not allow rephotographing of the original for any purpose, nor the handling of manuscripts by visiting scholars unless they can prove their absolute need to see the original to clear up some palaeographical point.

I can tell you that it was an absorbing and exciting experience to go through the newly-bound book to select the 304 openings which are needed in order to display a different one for every day in the year that the library is open. (We were always reputed to "turn a page every day," but, in fact, it is only since the book has been rebound that this practice has been maintained.) It was really a matter of making up my mind what to leave out; some pages show more signs of wear, or are much less decorative than others. In the end, however, the thirty-six openings to be omitted were decided upon. My experience was this, and it is one that has not, to my knowledge, been noted before: each Gospel begins quietly with comparatively little illumination-except, of course, for the gorgeous opening page, for it is the ordinary text pages I am talking aboutbut as the Gospel story unfolds itself, so the decoration increases in quantity, and as we reach the events of Holy Week and the Passion, the colorful initial letters occur every few lines and become more elaborate and exuberant in design, as if the artists were carried along by an urge to glorify in their own way the story of

(Continued on page 430) 
of Rochester Press for the Association of College and Research Libraries, 1958. (ix, 1161. diagr., tables. $28 \mathrm{~cm}$. ACRL MICROCARD SERIES, no. 95) Thesis (M.S. in L.S.)-Catholic University of America, 1957. Bibliography: 1. 103-105. 3 cards. $\$ .75$.

The purpose of this study is to relate the history of the founding of the Syrian Protestant College Library and its growth and de- velopment into the modern university library system which exists at the American University of Beirut today. It proposes, moreover, to show the influence which the University Library's Eastern environment has had upon the goals which it has set, the problems it has faced, the book collections it has formed, and the services it has rendered not only to Beirut and the University community but to the entire Middle East.

\section{Rare Book Librarian}

(Continued from page 394)

the approaching climax of Christ's work on earth.

I could go on talking about the Book of Kells, but with one more point, which I feel is not inappropriate, I will conclude that topic and, indeed, my talk. We do not know where the Book of Kells was written; as a Scot perhaps I may be excused for a certain bias towards Iona, off the west coast of Scotland, where there was a scriptorium. There is no evidence of any scriptorium having existed in Kells, but lack of evidence is no proof. We do know that the Book was kept in the town of Kells, which is in County Meath, now in the Republic of Ireland, at least from the year 1006, when we have the first historical record of its existence in the account given of its theft from the great church of Kells and its subsequent recovery half-buried in the ground, right through the middle-ages down to the mid-seventeenth century. And then, according to the general belief, it came to Trinity College along with Archbishop Ussher's other books in 1661. And what was the basis for this belief? Why, the Archbishop had written his name in the Book on fol. 334 verso! Yes, that is true, but it is not an ownership inscription; it is merely a signed attestation that he had counted the leaves and found them to be so-and-so many, just as you or I today might collate a book in our library and note and initial our findings in pencil on the inside of the front or back cover. Nowadays, if someone credited us with the ownership of a book in which we had jotted and initialed the collation, we would question that person's sanity. You see it is possible to make wrong infer. ences, and our enquiring minds must always be critical about everything we find in getting to know our books. So I end on a note of warning, but don't let that discourage you. Get to know all about your books and cherish them, for you are the custodians of our inheritance. 